\title{
PEMANFAATAN RESI GUDANG SEBAGAI OPSI OPTIMALISASI SUPPLY CHAIN SEBAGAI ALTERNATIF SOLUSI HARGA PANEN ANJLOK PADA KELOMPOK TANI
}

\author{
Handy Nur Cahya \\ Manajemen, Fakultas Ekonomi dan Bisnis, Universitas Dian Nuswantoro \\ handy.nur@dsn.dinus.ac.id
}

Diterima 12 Maret 2019, Disetujui 29 Maret 2019

\begin{abstract}
Abstrak
Petani merupakan salah satu penggerak roda perekonomian bangsa Indonesia. Sejak dahulu negeri agraris Indonesia tidak pernah lepas dari pertanian padi. Namun, kesejahteraan petani belum sepenuhnya baik. Panen raya yang semestinya membawa suka cita dan keuntungan, ternyata tidak selalu mutlak mengenai keuntungan. Panen raya kerap disertai masalah seperti harga jual gabah yang anjlok dikarenakan suplai yang melimpah. Tujuan dari penelitian ini adalah untuk menemukan bagaimana petani melalui kelompok tani dapat mengoptimalkan alur supply chain untuk mengatasi masalah klasik berupa harga jual rendah saat panen raya. Penelitian ini dilakukan secara descriptive research, dengan melakukan observasi pada kelompok tani Tirta Jaya Demak, memappingkan alur supply chain yang ada, dan menemukan solusi optimalisasi pada alur supply chain kelompok tani Tirta Jaya Demak. Hasil penelitian menunjukkan adanya ketidakoptimalan channel distribusi hasil pertanian, dan sistem resi gudang merupakan alternatif yang tepat, dan dapat diaplikasikan sebagai salah satu channel distribusi alternatif untuk mengatasi harga jual gabah yang anjlok pada saat panen raya.
\end{abstract}

Kata Kunci : sistem resi gudang, pertanian, rantai pasokan

\begin{abstract}
TSince long ago this agricultural country, Indonesia has never been separated from rice farming. However, the welfare of farmers has not been fully good. The harvest season that should bring joy and profit, not always absolute about the full benefits. Harvest season are often accompanied by problems such as drop of selling price due to abundant supply. The purpose of this study is to diclose that farmer groups can optimize the supply chain flow to overcome the drop of selling price. This research was conducted in descriptive research, by conducting direct observations on Tirta Jaya farmer groups in Demak, then mapping the existing supply chain flow, and finally finding optimization solutions in the flow. The results of this study indicate there is an unoptimal distribution channel for agricultural products, and the warehouse receipt system is the right alternative, and can be applied as one of the new distribution channels to overcome the drop of selling price during the harvest.
\end{abstract}

Keywords: warehouse receipt system, agriculture, supply chain. 


\section{PENDAHULUAN}

Petani merupakan salah satu penggerak roda perekonomian bangsa Indonesia. Sejak dahulu negeri agraris Indonesia tidak pernah lepas dari kegiatan pertanian. Salah satu kegiatan pertanian yang sangat akrab kita temui adalah pertanian padi, yang komoditas hasilnya adalah berupa gabah, yang kemudian diolah menjadi beras, makanan pokok masyarakat Indonesia.

Berbicara mengenai pertanian, tentunya akan berujung dengan panen raya. Panen raya seharusnya berhubungan dengan suka cita dan sesuatu yang melimpah. Namun, panen raya yang terjadi tidak selalu berbicara mengenai keuntungan seutuhnya. Panen raya kerap memicu masalah tersendiri bagi petani, seperti harga jual yang rendah dikarenakan melimpahnya hasil panen padi (BlitarKab, 2013). Sesuai dengan hukum penawaran dan permintaan, harga komoditas gabah akan anjlok ketika stok terlampau banyak di pasar. Harga yang anjlok inilah yang kerap dikeluhkan masyarakat petani, seperti yang terjadi di kelompok tani Tirta Jaya Demak ini. Keuntungan mereka justru tergerus karena panen raya yang terjadi. Akibatnya, terjadi kesulitan dana untuk mempersiapkan siklus pertanian mendatang (Ashari, 2013).

Secara logika, jika harga jual rendah, seharusnya petani memiliki opsi untuk melakukan penundaan penjualan, tapi dikerenakan keperluan uang untuk melakukan mempersiapkan siklus pertanian selanjutnya, maka mau tidak mau petani harus melakukan penjualan produk pertaniannya pada waktu harga anjlok. Hal demikian membuat keuntungan petani tergerus dan menipis, sehingga hal inilah yang diindikasi menjadi penyebab kesejahteraan petani yang sulit meningkat.

Widyarto (2012), menyatakan bahwa salah
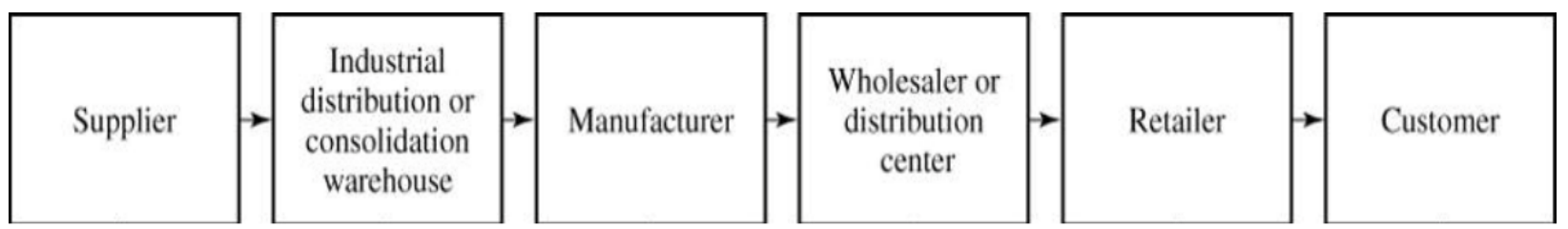

Gambar 1: Konsep Supply Chain Management Sumber: Heizer dan Render (2015)

Lebih lanjut, mempelajari SCM bagi pelaku usaha merupakan hal penting, karena dapat bermanfaat untuk mengkoordinasi kegiatan dalam sebuah alur supply chain sebagai upaya memaksimalkan satu upaya untuk mereduksi biaya operasional pertanian adalah melalui optimalisasi channel distribusi, baik optimalisasi dari sisi supplier, aliran material dalam proses produksi, sampai dengan distribusi produk ke tangan konsumen. Distribusi yang optimal dalam hal ini dapat dicapai melalui penerapan konsep Supply Chain Management (SCM) sehingga bisa dioptimalkan sisi sisi tertentu yang dianggap kurang optimal.

Tujuan dari penelitian ini adalah untuk memetakan alur supply chain pertanian padi yang ada pada kelompok tani Tirta Jaya Demak, dan kemudian menemukan bagian dari alur supply chain mana yang belum optimal. Selanjutnya, memberikan opsi bagi kelompok tani untuk dapat mengoptimalkan alur supply chain yang ada. Sehingga, alur supply chain kegiatan pertanian mereka menjadi lebih optimal, dan para petani memperoleh keuntungan dari optimalisasi supply chain ini. Dikarenakan waktu penelitian yang terbatas, maka optimalisasi alur supply chain penelitian ini difokuskan hanya pada faktor yang berkaitan dengan penyebab harga komoditas gabah yang anjlok pada waktu panen raya.

\section{KAJIAN TEORI}

Menurut Heizer \& Render (2015), Supply Chain Management (SCM) merupakan suatu koordinasi dan perpindahan barang dari mulai pemasok, perusahaan manufaktur/jasa, perusahaan distributor, perusahaan pengecer, retailer, hingga sampai ke konsumen akhir. Mempelajari SCM bertujuan untuk dapat memetakan bagian bagian yang terlibat dalam sebuah alur supply chain sebuah bisnis, dan dapat menganalisa, bagian mana yang bisa dioptimalkan untuk menghasilkan sebuah alur supply chain yang efisien.

keunggulan kompetitif dan memberikan manfaat sebesar besarnya bagi semua pihak yang terlibat dalam rangkaian supply chain utuh (Briones, 2016). 
Terdapat dua macam supply chain menurut Webster (2009), yaitu internal supply chain dan external supply chain. Internal supply chain merupakan alur supply chain yang berkaitan dengan perpindahan barang dalam suatu perusahaan saja. Sedangkan external supply chain merupakan alur supply chain yang melibatkan dua atau lebih perusahaan yang saling terkait dalam satu alur supply chain utuh yang sama.

Adapun alur supply chain tersaji pada Gambar 1, Mengenai Konsep Supply Chain Management:

Secara umum sistem rantai pasokan meliputi supplier, produsen, distributor, retailer, dan konsumen akhir. Terlihat sederhana, tapi didalam sebuah alur supply chain sejatinya adalah suatu jaringan yang cukup rumit. Sebagai produsen misalnya, harus memilih supplier dengan banyak pertimbangan.

Menentukan supplier dengan harga jual yang paling kompetitif, memilih supplier yang dapat mensuplay kebutuhan produksi perusahaan secara berkesinambungan, memilih supplier dengan kualitas barang terbaik, merupakan beberapa hal yang cukup kompleks untuk dilakukan. Begitu pula bagian lain dari alur supply chain, mereka memiliki tingkat kompleksitas masing masing didalam aktivitas mereka.

Berdasarkan UU No. 9 tahun 2006 mengenai Sistem Resi Gudang, resi gudang merupakan surat berharga atau dokumen bukti kepemilikan atas barang yang disimpan di Gudang yang diterbitkan oleh Pengelola Gudang dibawah kementerian Perdagangan. Sistem resi gudang ini berkaitan dengan serangkaian kegiatan berupa menerbitkan, mengalihkan, menjaminkan, dan penyelesaian transaksi resi gudang.

Sistem resi gudang (SRG) sepenuhnya dikelola oleh kementrian perdagangan beserta kementrian pertanian sebagai penggunanya. Gudang SRG ini kemudian beroperasi dibawah Badan Pengawas yang berada setingkat dibawah Kementrian Perdagangan. Bukti kepemilikan resi SRG adalah dapat dialihkan, dijadikan syarat jaminan utang, ataupun dapat digunakan sebagai dokumen penyerahan barang. Dalam hal Resi Gudang sebagai dokumen kepemilikan, resi SRG dapat dijadikan jaminan utang kepada bank terkait tanpa perlu adanya agunan lainnya.

Secara umum Resi Gudang memiliki karakteristik sebagai berikut menurut UU No. 9 tahun 2006: (1) Hanya dapat diterbitkan oleh lembaga yang terlah tersertifikasi oleh Badan Pengawas; (2) Derivatif resi gudang hanya dapat diterbitkan oleh lembaga keuangan bank, non bank, dan pedagang berjangka yang telah mendapat persetujuan dari Badan Pengawas; (3) Resi gudang yang diterbitkan dapat berupa resi gudang atas nama dan resi gudang atas perintah; (4) Di dalam resi gudang sekurangnya harus memuat judul resi gudang, nama dan alamat pemilik barang, lokasi gudang penyimpanan barang, dan tanggal penerbitan, nomor penerbitan, waktu jatuh tempo, deskripsi barang, biaya penyimpanan, dan stampel serta tanda tangan pengelola gudang; (5) Resi gudang dan derivatif resi gudang dapat diperdagangkan baik di bursa maupun diluar bursa; (6) Pengalihan resi gudang dapat terjadi karena, pewarisan, hibah, jual beli, dan atau sebab sebab lain yang dibenarkan.

Terdapat syarat yang harus dipenuhi jika akan melakukan penyimpanan produk di dalam gudang SRG, yaitu komoditas produk harus memiliki daya simpan paling sedikit 3 bulan, produk harus memenuhi standar mutu tertentu, dan ada kuota minimal yang harus disiapkan agar bisa disimpan di gudang SRG.

Berdasarkan Permendag No. 26/M- DAG/PER/ 6/2007, barang barang komoditas yang dapat disimpan di gudang SRG berupa komoditas gabah, beras, jagung, kopi, kakao, lada, karet, dan rumput laut.

Undang Undang no 9 tahun 2006 menjelaskan bahwa regulator SRG utama berada di tangan Kementrian Perdagangan.Kemudian, SRG dilaksanakan oleh beberapa lembaga, yaitu Badan Pengawas, Pengelola Gudang, Lembaga Penilaian Kesesuaian, dan Pusat Registrasi. Badan Pengawas bertugas melakukan seluruh pengawasan SRG dari hulu ke hilir, apakah sudah sesuai dengan aturan yang ada atau belum. Pengelola Gudang bertugas dan bertanggung jawab untuk mengelola gudang dan memastikan keamanan barang komoditas yang disimpan di gudang SRG.

I.emhaøa Penilai Kesesuaian hertıøas

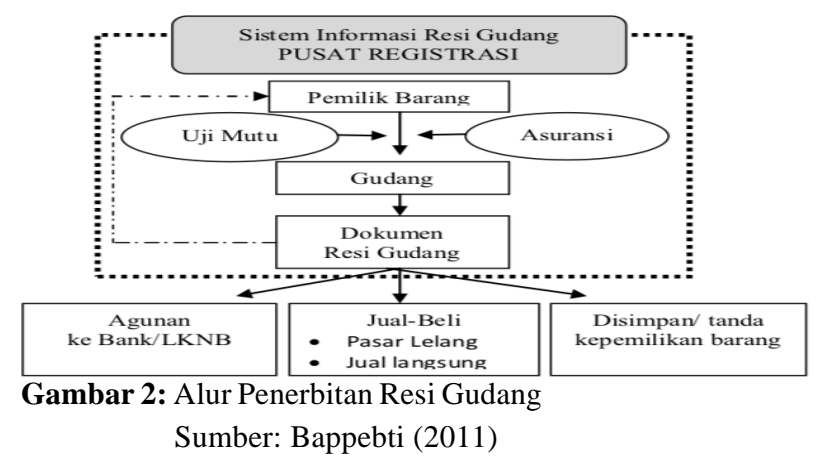


Adapun penerbitan resi gudang diatur dalam peraturan Bappebti tahun 2011, tersaji dalam Gambar 2. Alur Penerbitan Resi Gudang. Alur penerbitan resi gudang diawali dengan pemilik komoditas barang mendatangi gudang SRG. Kemudian pemilik komoditas barang melakukan registrasi dengan disertai proses uji mutu dan asuransi di Pusat Registrasi gudang SRG. Setelah lolos pada tahap uji mutu, baru dokumen resi gudang dapat diterbitkan beserta nilai komodi yang tercantum dalam resi gudang yang diterbitkan. Selanjutnya resi gudang tersebut dapat digunakan sebagai agunan ke bank, untuk kegiatan jual beli di pasar lelang, dan atau disimpan sebagai sebuah bukti tanda kepemilikan barang (Bappebti, 2011).

Jumlah gudang SRG sendiri per Desember 2018, terdapat 130 Gudang SRG yang telah beroperasi secara nasional. Dari jumlah tersebut sebanyak 80 Gudang SRG merupakan gudang yang dibangun oleh pemerintah, dan 50 gudang merupakan gudang milik swasta/bumn/koperasi yang telah memperoleh ijin operasional sebagai gudang SRG dari Bapebti (SRG Kemendag, 2018).

Pada wilayah operasional kawasan Demak sendiri, terdapat dua gudang SRG, yaitu Gudang SRG Margomulyo, dan Gudang SRG Dempet. Gudang SRG Margomulyo beralamat di Jalan Raya Demak - Jepara KM 10 Desa Mulyorejo Kecamatan Demak, Kabupaten Demak, Jawa Tengah. Kapasitas gudang SRG Mulyorejo sendiri adalah 1500 tondan gudang ini dibangun atas lahan seluas 700 m2. Gudang SRG Mulyorejo dapat ditujukan untuk menampung komoditas jenis gabah, beras dan jagung.

\section{METODE}

Penelitian ini merupan descriptive research. Data diperoleh dengan cara dengan melakukan observasi langsung pada kelompok tani Tirta Jaya Demak, berdiskusi, dan mengobservasi guna memappingkan alur supply chain yang ada. Selanjutnya, dari alur supply chain yang telah diobservasi, peneliti menentukan letak ketidakoptimalan supply chain berdasarkan prinsip-prinsip supply chain management.

Tahap berikutnya adalah memberikan opsi bagi kelompok tani untuk dapat mengoptimalkan alur supply chain yang ada. Sehingga, alur supply chain kegiatan pertanian kelompok tani menjadi lebih optimal. Output akhir yang diharapkan adalah anggota kelompok tani memperoleh keuntungan dari optimalisasi alur supply chain dalam kaitan dengan anjloknya harga komoditas padi ketika panen raya terjadi.

\section{HASIL DAN PEMBAHASAN}

Petani padi, profesi di bidang pertanian yang merupakan profesi legendaris dari sejak jaman dahulu seharusnya telah memperoleh posisi mapan dalam kancah bisnis di Indonesia jika melihat keberlangsungan mereka yang sudah ada beribu ribu tahun lamanya. Namun, gayung tidak selalu bersambut, kehidupan petani di masa kini sebagian besar masih dibawah garis layak. Meskipun sebagian diantaranya memang telah ada yang berkecukupan dan mampu mengembangkan bisnis pertaniannya.

Seperti yang ditemukan di Kelompok Tani Tirta Jaya Demak, dalam kelompok tani ini ditemukan petani yang memang sudah berkecukupan, karena memang mereka dibesarkan dari keluarga berpunya. Tapi, sebagian besar lainnya tidak memiliki kesempatan yang sama, dikarenakan mereka berasal dari keluarga biasa. Hasil observasi menunjukkan bahwa permasalahan kesejahteraan pertanian yang ada di Kelompok Tani Tirta Jaya Demak ini ada dua macam kategori utama. Dua kategori tersebut adalah kategori internal petani dan kategori eksternal (Anugerah, 2015). Penyebab pertama dalam kategori internal petani, dimana sistem pertanian yang dilakukan masih konvensional. Dalam artian, petani melakukan kegiatan pertanian dengan cara yang masih sama dengan cara bertani puluhan tahun lalu. Tidak ada pembaharuan teknologi yang signifikan dalam pertanian ini (Rahmawati, 2015). Hal ini dilakukan oleh hampir seluruh anggota kelompok tani Tirta Jaya Demak dan menyebabkan pertanian yang ada hasilnya cenderung selalu stagnan, tidak ada peningkatan yang signifikan terjadi didalamnya.

Mari bandingkan dengan pertanian di Inggris misalnya, berdasarkan CNBC dan CBSNEWS (2017) negeri 4 musim ini sudah menggunakan teknologi canggih dalam pertaniannya. Inggris bisa melakukan kegiatan pertanian di bawah tanah, yang benar benar bisa dikontrol kapan akan bertani dan kapan akan panen, sehingga siklus panen bisa dijaga. Akibatnya bisa menciptakan keseimbangan permintaan \& penawaran produk hasil turunan padi di masyarakat yang berimplikasi pada harga komoditas pertanian padi menjadi stabil.

Sejalan dengan Onumah (2010), keengganan generasi penerus (anak) dalam melanjutkan pertanian juga merupakan salah satu penyebab tidak berkembangnya pertanian di kelompok tani Tirta Jaya Demak. Anak anak masa kini lebih memilih bersekolah, kuliah, dan kemudian 
bekerja di tempat lain yang mereka anggap sebagai tempat kerja yang bonafide (Masini, 2012). Para orang tua pun juga mendukung dan mendorong anak mereka untuk keputusan tersebut dengan alasan masa depan yang lebih baik. Praktis, para petani yang notabene telah berusia tua ini kemudian melakukan praktek kegiatan pertanian dengan cara bertani yang masih seperti puluhan tahun yang lalu, seperti pada awal mereka belajar bertani.

Selanjutnya, faktor eksternal dari petani yang mempengaruhi kesejahteraan petani padi adalah faktor panen raya. Sejalan dengan hukum permintaan dan penawaran, ketika barang terbatas jumlahnya, harga barang akan naik, dan ketika ketersediaan barang melimpah, dengan jumlah konsumen yang ada adalah tetap, maka harga akan turun (MirandaAckerman, 2018). Hal serupa terjadi pula didalam pertanian di Kelompok Tani Demak ini, ketika panen raya berlangsung, harga komoditas gabah dan beras akan anjlok.

Pada kondisi harga anjlok sewaktu panen raya, seharusnya petani menunda penjualan produk hasil pertanian agar tidak rugi, dan menjual ketika harga di pasar sudah membaik (Pellegrino, 2018). Tapi, kebutuhan akan uang untuk meneruskan bercocok tanam di siklus tanam selanjutnya memaksa petani untuk menjual hasil panen mereka pada waktu panen raya.

Ketiadaan pilihan lain mengakibatkan para petani selalu tidak dapat memperoleh keuntungan maksimal. Imbasnya, kesejahteraan petani tentunya sulit meningkat karena setiap panen raya, yang terjadi adalah harga komoditas gabah dan beras anjlok dan keuntungan yang diperoleh pada saat panen raya menjadi sangat terbatas (Abdullah, 2017).

Adapun alur supply chain yang dilakukan petani di kelompok tani Tirta Jaya Demak secara umum tergambar dalam ilustrasi gambar 3 berikut:

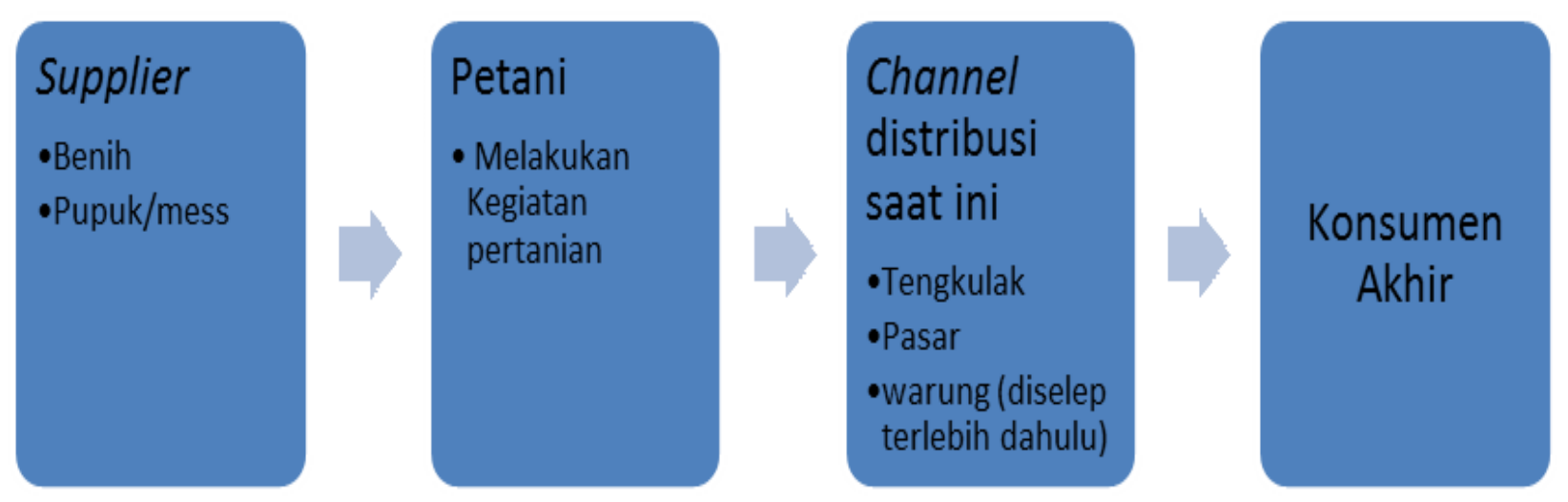

Gambar 3: Alur Supply Chain petani kelompok tani Tirta Jaya Demak Sumber: Data Primer yang diolah (2018)

Pemerintah negara Republik Indonesia melihat hal ini sebagai suatu kondisi yang sangat perlu ditangani segera. Pada tahun 2006. Pemerintah Indonesia melalui Kementerian Perdagangan mengeluarkan UU No. 9 tahun 2006 mengenai Sistem Resi Gudang. Sistem resi gudang ini merupakan salah satu solusi dari pemerintah yang prihatin terhadap dunia pertanian Indonesia. Sistem resi gudang memfasilitasi terwujudnya kemudahan tindak lanjut dalam distribusi produk hasil pertanian, sebagai salah satu alternatif jalur perolehan akses modal dan penundaan penjualan barang komoditas hasil pertanian (Coulter, 2002).

Sistem resi gudang diinisiasi sebagai salah satu solusi sistem pembiayaan perdagangan untuk menjamin kelancaran usaha petani, yang merupakan bagian dari Usaha Kecil dan Menengah (UMKM), yang pada umumnya bermasalah dengan pembiayaan usaha karena ketebatasan akses dan jaminan kredit
(Lembar Penjelasan UU No. 9 tahun 2006). Hal ini sesuai dengan kondisi petani di kelompok tani Tirta Jaya Demak ini, kebanyakan mereka adalah dari melakukan pinjaman dana. Ketika harga komoditas gabah / beras di pasaran sudah membaik, petani dapat melakukan penjualan produk pertanian mereka yang mereka simpan di gudang SRG kemudian, tentunya dengan harga yang lebih layak.

Walau demikian, Sistem Resi gudang ini tidak mudah untuk dilaksanakan. Banyak kendala kendala teknis yang menyebabkan kurang bergaungnya Sistem Resi Gudang di masyarakat. Kendala teknis seperti kurangnya sosialisasi yang mendalam bagi, minimnya pendampingan dari instansi terkait dalam pelaksanaan di lapangan, serta kurang aktifnya sosialisasi dari Bank terkait kepada petani merupakan faktor - faktor yang membuat SRG kurang dimanfaatkan keberadaannya (Ashari, 2011). 
Satriyo (2014), dalam penelitiannya mengenai Pelaksanaan Pembinaan Sistem Resi Gudang di Kabupaten Blitar menemukan fakta bahwa masih terkendalanya pelaksanaan sistem resi gudang di kabupaten Blitar. Hal ini diantaranya disebabkan oleh kelembagaankelompok tani yang masih lemah. Dalam artian sistem kelembagaan di kolompok tadi Blitar yang diobserbasi belum baik secara menjalankan fungsi lembaga, maupun berkoordinasi dengan berbagai pihak terkait. Kelembagaan masihberupa sekedar ada lembaga dan belum mengoptimalkan fungsi/peran lembaga kelompok tanitersebut. Lembaga kelompok tani belum menginisiasi bagaimana mengoptimalkan supply chain komoditas pertanian bagi anggota kelompoknya. Hal ini dikarena adanya terkait tanpa adanya pendamping yang mengarahkan dan menemani. Hal demikian juga sama seperti yang terjadi pada kelompok tani Tirta Jaya. Kelompok Tani mengalami kesulitan dalam akses ke resi gudang karena kurangnya pendampingan aktif dari berbagai pihak. Akibatnya sistem resi gudang juga belum dioptimalkan keberadaannya oleh petani Tirta Jaya Demak. Implikasinya adalah kesejahteraan masyarakat petani yang masih rendah walau telah tersedia sistem resi gudang di Demak.

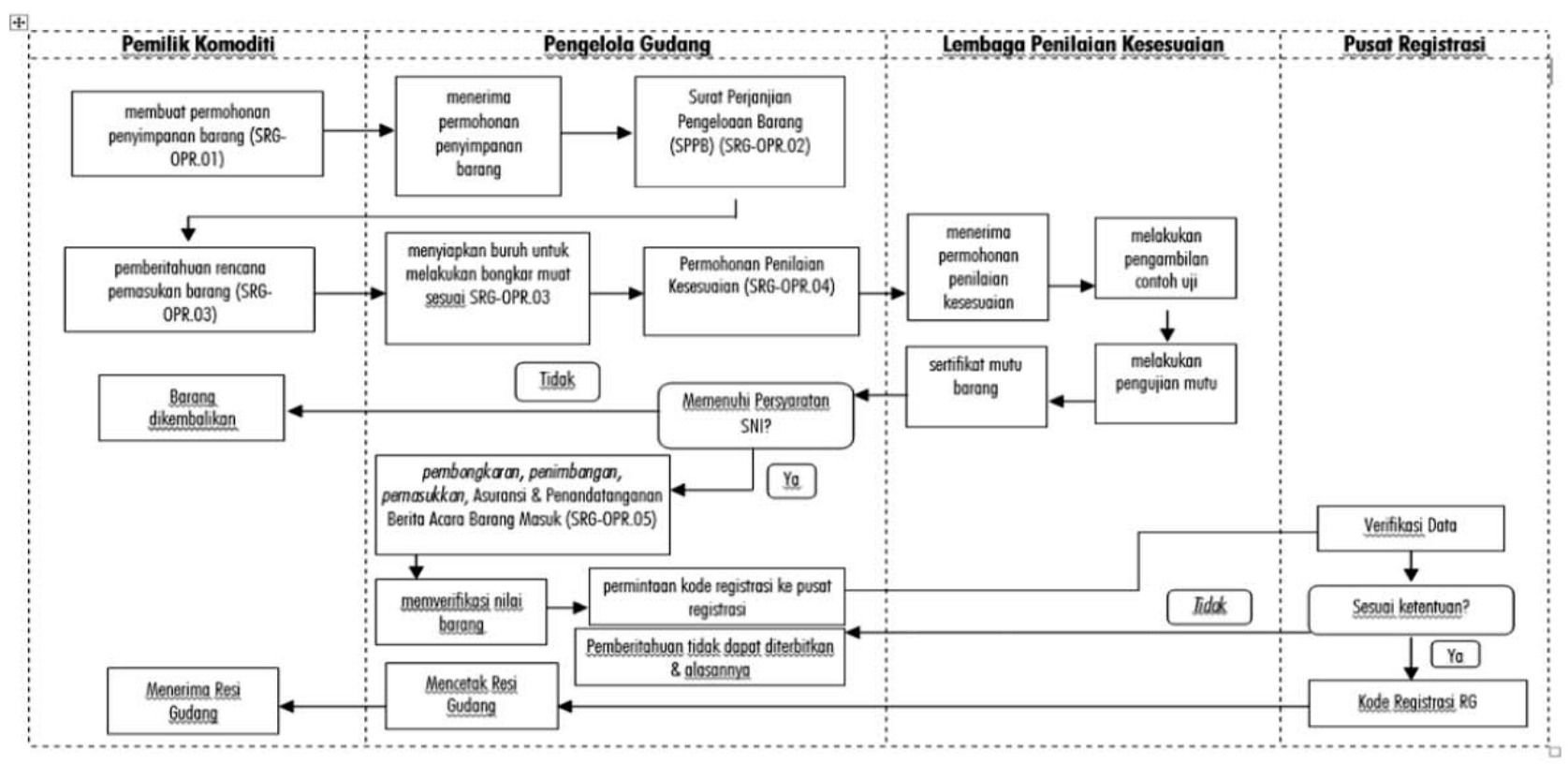

Gambar 4: Alur Penerbitan Resi Gudang Sumber: UU No 9 Tahun 2006 (2006)

keterbatasan pendidikan dari anggota maupun pengurus kelompok tani tersebut.

Penyebab lain adalah karena terbatasnya sosialisasi mengenai sistem resi gudang oleh intansi terkait, baik Dinas Perdagangan, Dinas Pertanian, maupun Dinas Perindustrian. Dinas terkait hanya dilakukan sekali atau dua kali saja sosialisasi kepada masyarakat kelompok tani. Jumlah tersebut ditengarai sangat kurang dalam membuat anggota kelompok tani menjadi paham betul mengenai sistem resi gudang.

Selanjutnya, bagian penting yang masih

kurang pada implementasi sistem resi gudang Kabupaten Blitar adalah, lemahnya pendampingan petani untuk mengakses segala proses pengurusan resi gudang. Masyarakat petani yang kebanyakan berada di usia dewasa hingga lanjut, dan mereka berpendidikan kurang, kesulitan dalam memberanikan diri untuk mendatangi lembaga-lembaga perkantoran Fachruddin (2017), dalam penelitiannya mengenai Evaluasi Prasyarat keberhasilan sistem Resi Gudang di Kabupaten Bantul menemukan fakta bahwa terjadinya penurunan kinerja SRG dari kurun waktu 2011-2016 dikarenakan kurang cukupnya sinergi dari stakeholder terkait pada SRG kabupaten Bantul. Dinas Perdagangan saja yang dilaporkan telah berperan aktif melakukan sosialisasi kepada masyarakat petani. Namun, sosialisi ini tidak berdampak signifikan karena keterbatasan jumlah staf yang dapat melakukan sosialisasi sekaligus pendampingan kepada kelompok tani. Terjadinya panen raya dan pelaksanaan sistem resi gudang yang kurang baik mengakibatkan harga komoditas gabah dan beras menjadi anjlok. Petani terpaksa menjual 
produk pertanian mereka ke pasar dengan harga yang cukup rendah. Hal demikian dilakukan karena kebutuhan akses dana bagi petani untuk mempersiapkan siklus tanam selanjutnya. Sama halnya dengan yang terjadi pada kelompok tani Tirta Jaya, kebutuhan akses akan modal untuk mempersiapkan siklus pertanian selanjutnya membuat petani terpaksa menjual hasil panen pada masa panen raya dengan harga yang rendah.

Dalam penelitian (Fachruddin, 2017) juga ditemukan bahwa masih sangat perlu adanya sosialisasi, edukasi, dan juga pendampingan yang lebih intensif kepada kelompok tani yang ada di Kabupaten Bantul agar gudang SRG Kabupaten Bantul dapat dioptimalkan keberadaannya. Edukasi dan pendampingan dapat dikolaborasikan antara semua pihak terkait, baik dari Dinas Perdagangan, Dinas Pertanian, Dinas Perindustrian, dan Bank terkait. Pengelola kelompok tani itu sendiri diharapkan dapat lebih proaktif agar kesejahteraan anggota kelompok tani dapat meningkat dengan memanfaatkan SRG yang ada di kabupaten Bantul. Maka berdasarkan temuan penelitian SRG Bantul, untuk dapat meningkatkan harga jual produk hasil pertanian di kelompok tani Tirta Jaya dengan sistem resi gudang, harus pula ada pendampingan dari seluruh pihak stakeholder resi gudang Demak. Baik yang aktif melakukan inisiatif pendampingan adalah para pengelola gudang SRG, ataupun dari pihak kelompok tani yang lebih aktif meminta pendampingan kepada stakeholder gudang SRG Demak.

Liliyah (2016), menerangkan bahwa memang di Indonesia secara umum implementasi sistem resi gudang belum berjalan dengan optimal. Hal ini berbeda dengan yang terjadi di Bulgaria. Di Bulgaria kesuksesan pelaksanaan SRG ditengarai karena pemerintah yang mewajibkan secara mutlak bahwa semua petani wajin melakukan penyimpanan hasil pertanian mereka ke gudang SRG. Berbeda dengan di Indonesia, sifat implementasi SRG masih berupa sukarela, yang tidak bersifat mengikat (wajib).

Sifat yang tidak mengikat ini, ditambah dengan sosialisasi dan pendampingan di level kelompok tani yang masih kurang, membuat sistem resi gudang di Indonesia belum berjalan sesuai harapan. Kebanyakan SRG yang ada di indonesia cenderung sepi peminat. Seperti yang terjadi di gudang SRG Bantul dan gudang SRG Blitar. Masalahnya sama, kurang sosialisasi dan minimnya pendampingan di level kelompok tani. Akibatnya menjadi kurang berhasilnya sistem resi gudang di wilayah tersebut. Maka, sosialisasi dan pendampingan menjadi faktor penting yang harus ada di gudang SRG Demak. Bagi kelompok tani Tirta Jaya sendiri, mengetahui pentingnya pendampingan dan sosialisai gudang SRG Demak bermanfaat untuk dapat sukses terlepas dari belenggu harga anjlok panen raya. Sehingga, aktif mencari informasi dan mengajukan pendampingan sangat dianjurkan agar dapat sukses memanfaatkan gudang SRG Demak.

Dari beberapa contoh gudang SRG yang telah dibahas, memang menunjukkan belum optimalnya pelaksanaan sistem resi gudang. Namun demikian, berbeda dengan gudang SRG yang berada di wilayah Cianjur. Khasanah (2016), dalam penelitiannya mengenai Efektifitas Implementasi Sistem Resi Gudang Komoditi Gabah di Kabupaten Cianjur menemukan bahwa implementasi SRG di Kabupaten Cianjur sudah berjalan efektif. Pada penelitian ini ditemukan bahwa adanya kerjasama, komunikasi, dan koordinasi yang supportif antar instansi yang ada, yaitu Dinas Perindustrian, Dinas Perdagangan, dan Dinas Pertanian yang saling bekerja sama dengan baik. Pendampingan di level koperasi/kelompok tani pun dilaksanakan dengan baik. Bahkan Bank terkait turut berpartisipasi aktif melakukan sosialisasi kepada kelompok tani dengan menerjunkan stafnya untuk melakukan jemput bola. Dengan adanya sinergi tersebut terbukti SRG di kabupaten Cianjur dapat berjalan dengan lancar dan efektif.

Kendala yang ditemui pada SRG kabupaten Cianjur adalah keterbatasan kapasitas SRG yang ada dan kurangnya pengalaman/pelatihan terhadap pengelola SRG. Kurangnya kapasitas gudang SRG berakibat pada ketidakmampuan pengelola dalam menerima pasokan hasil pertanian. Hal demikian karena memang kapasitas gudang yang sudah tidak memadahi akibat antusias warga petani memanfaatkan gudang SRG yang ada. Akibatnya petani yang memerlukan SRG tidak dapat dilayani dan terpaksa menjual produknya di pasar secara langsung dengan harga yang sedang anjlok. 
Tabel 1. Perkembangan Penerbitan dan Nilai RG serta Nilai Pembiayaan

\begin{tabular}{ccccc}
\hline \multirow{2}{*}{ Tahun } & \multicolumn{2}{c}{ Penerbitan } & \multicolumn{2}{c}{ Pembiayaan } \\
\cline { 2 - 5 } & Jumlah RG & Nilai (Rp Juta) & Jumlah RG & Nilai (Rp juta) \\
\hline 2008 & 16 & 1.432 & 6 & 313 \\
2009 & 13 & 553 & 5 & 136 \\
2010 & 57 & 8.679 & 35 & 4.216 \\
2011 & 271 & 40.068 & 218 & 24.050 \\
2012 & 379 & 93.183 & 334 & 58.654 \\
2013 & 480 & 93.210 & 377 & 53.363 \\
2014 & 596 & 124.966 & 569 & 84.780 \\
Total & 1.812 & 362.090 & 1.544 & 225.513 \\
\hline
\end{tabular}

Kurangnya pengalaman manajemen pergudangan pada staff gudang diindikasikan terlalu lama proses manajemen digudang SRG di gudang di Cianjur. Hal demikian perlu penanganan khusus berupa training mengenai manajemen gudang SRG agar proses administrasi dan pemanfaatan gudang bisa berjalan optimal.

Keberhasilan/ efektifitas penggunaan gudang SRG di kabupaten Cianjur ini merupakan salah satu contoh nyata sinergi bersama yang dilaksanakan semua stakeholder dalam mensukseskan program SRG untuk kesejahteraan bersama. Hal ini sejalan dengan data dari Bappebti, Kementrian perdagangan (2014) mengenai Perkembangan Penerbitan dan Nilai Resi Gudang serta Nilai Pembiayaan, yang menunjukkan peningkatan kinerja dari tahun ketahun mulai dari tahun 2008-2014, seperti yang tersaji pada Tabel 1 mengenai Perkembangan Penerbitan dan nilai RG serta nilai Pembiayaan.

Dari berbagai penilitian mengenai pelaksanaan resi sistem gudang yang telah dibahas, termasuk kendala kendala dan faktor yang membuat keberhasilan implementasi SRG, menunjukan adanya kesamaan kondisi petani dan ketersediaan gudang SRG, kesamaan kondisi petani adalah memiliki komoditas andalan pertanian berupa gabah dan kelompok tani yang ada masih berupa kelembagaan sederhana yang sangat perlu pendampingan. Kesamaan ketersediaan gudang juga terpenuhi, bahkan di Demak tersedia dua gudang SRG, yakni Gudang SRG Mulyorejo dan Gudang SRG Dempet.

Sehingga, berdasarkan kesamaan kondisi kelompok tani di Blitar, Bantul, dan Cianjur yang mengalami harga anjlok pada saat panen raya, maka ketika pemafaatan gudang SRG diimplementasikan di kelompok Tani Tirta Jaya Demak, seharusnya dapat membantu petani untuk meningkatkan kesejahteraan dengan memperoleh harga jual yang lebih baik. Peluang ini dikuatkan dengan komoditas gabah hasil kelompok tani Tirta Jaya Demak, yang sesuai dengan komoditas pioner dalam pemanfaatan gudang SRG secara nasional seperti tersaji dalam Tabel 2 berikut.

Tabel 2: Nilai Resi Gudang Berdasarkan Jenis Komoditas Utama

\begin{tabular}{|l|c|c|c|c|}
\hline \multirow{2}{*}{\multicolumn{1}{c|}{ Komoditas }} & \multicolumn{2}{|c|}{ Penerbitan } & \multicolumn{2}{c|}{ Pembiayaan } \\
\cline { 2 - 5 } & Jumlah RG & $\begin{array}{c}\text { Nilai } \\
\text { (Rp miliar) }\end{array}$ & Jumlah RG & $\begin{array}{c}\text { Nilai } \\
\text { (Rp miliar) }\end{array}$ \\
\hline Gabah & 1.636 & 306,291 & 1.407 & 192,614 \\
\hline Beras & 93 & 38,322 & 83 & 23,666 \\
\hline Jagung & 66 & 15,034 & 44 & 9,082 \\
\hline Kopi & 15 & 1,111 & 10 & 151 \\
\hline
\end{tabular}

Sumber: Bappebti, Kementerian Perdagangan (2014)

tanpa harus menjual gabah/beras pada waktu panen raya dengan harga jual yang anjlok. Ketika pemanfaatan gudang SRG dilakukan oleh kelompok Tani Tirta Jaya Demak, diharapkan value gabah dapat meningkat. Value disini adalah harga gabah nilainya tidak harus dijual rendah ketika panen raya. Melainkan bisa disimpan sementara di gudang SRG untuk memperoleh bukti resi gudang. Dengan bukti resi penyimpanan tersebut, petani bisa mengajukan pinjaman dana ke bank tanpa perlu agunan dalam bentuk lain. Ataupun resi gudang tersebut bisa untuk diperjual belikan. 
Pada tabel 2 terihat bahwa gabah menjadi komoditas tertinggi volume penggunaan/ pemanfaatan terhadap gudang SRG, sehingga hal ini menunjukkan kinerja gudang SRG dapat diandalkan oleh petani untuk membantu petani memperoleh dana. Adanya gudang SRG dalam alur supply chain petani di kelompok tani Tirta Jaya Demak, membuat komposisi channel distribusi produk pertanian menjadi bertambah variasinya. Tambahan channel distribusi ini membuat petani tidak harus menjual produk pertanian mereka ke channel distribusi yang telah ada, yaitu tengkulak, pasar, dan warung yang ada disekitar mereka. Melainkan petani dapat menggunakan gudang SRG sebagai alternatif channel distribusi penyimpanan produk hasil pertanian. Harapannya agar petani tidak mengalami penjualan di harga pasar yang sedang anjlok jika menjual ke tengkulak, maupun pasar. selanjutnya tanpa harus menjual hasil panen pada waktu panen raya. Yang berarti, masalah utama berupa harga jual gabah/beras yang anjlok ketika panen raya terjadi dapat terakomodasi solusinya.

Kemudian, pada saat harga gabah / beras di pasar sudah membaik petani dapat menjual gabah dengan harga yang lebih tinggi dibandingkan dengan menjual ke pasar ketika panen raya. Secara ringkas opsi dan kegunaan gudang SRG akan dapat terlihat di Gambar 5.

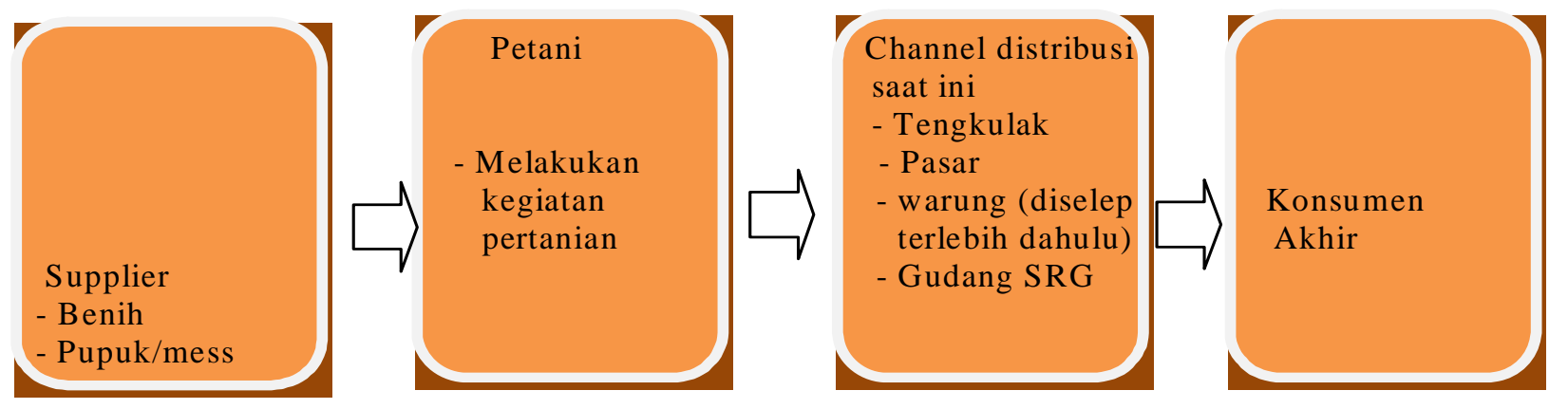

Gambar 5. Alur Supply Chain petani kelompok tani Tirta Jaya Demak (termodifikasi) Sumber: Data Primer yang diolah(2018)

\section{SIMPULAN SARAN}

Berdasarkan pembahasan yang telah dilakukan, terlihat bahwa sistem resi gudang merupakan cara ampuh yang diformulasikan oleh pemerintah untuk membantu petani serta merupakan upaya peningkatan ketahanan pangan nasional. Melihat adanya faktor kesamaan yaitu kondisi petani, dan ketersediaan gudang SRG, maka kelompok tani Tirta Jaya Demak dapat pula memanfaatkan sistem resi gudang sebagai alternatif channel distribusi produk hasil pertanian. Untuk memastikan pelaksanaan sistem resi gudang berhasil pada kelompok tani Tirta Jaya Demak ini, maka seluruh stakeholder, yakni Dinas Perdagangan, Dinas Pertanian, dan Dinas Perindustrian, serta Bank terkait sebaiknya turut berpartisipasi aktif, terutama pendampingan secara langsung kepada kelompok tani.

Dengan adanya opsi penggunaan gudang SRG dalam alur supply chain petani di kelompok tani Tirta Jaya Demak, membuat komposisi channel distribusi produk bertambah. Tambahan gudang SRG sebagai salah satu channel distribusi memberikan keleluasaan bagi petani untuk memperoleh dana guna mempersiapkan siklus tanam selanjutnya tanpa harus menjual hasil panen pada waktu panen raya. Yang berarti, masalah utama berupa harga jual gabah/beras yang anjlok ketika panen raya terjadi dapat terakomodasi solusinya.

\section{DAFTAR PUSTAKA}

Anugerah, Iwan Setiaji.; Erwidodo; Erma Suryani.

2015. Sistem Resi Gudang Dalam Perspektif Kelembagaan Pengelola Dan Pengguna Di Kabupaten Subang: Studi Kasus KSU Annisa. Bogor: Pusat Sosial Ekonomi dan Kebijakan Pertanian Ashari; Ening Ariningsih; Yana Supriyatna; Cut Rabiatul Adawiyah; Sri Suharyono. 2013. Kajian Efektivitas Sistem Resi Gudang Dalam Stabilisasi Pendapatan Petani. Jakarta: pusat sosial ekonomi dan kebijakan pertanian badan penelitian dan pengembangan pertanian

Bappebti. 2011. Sistem Resi Gudang Sebagai Instrumen Pembiayaan. Makalah disampaikan pada Workshop Penguatan Kelembagaan Sistem Resi Gudang dalam Mendukung Pembiayaan Sektor Pertanian, Best Western Mangga Dua Hotel \& Residence. Jakarta: Menko Perekonomian. 
Bappebti. 2014. Laporan Rekapitulasi Resi Gudang Tahun. Jakarta: Kementerian Perdagangan.

Bappebti. 2017. Panduan Pelaksanaan Sistem Resi Gudang. Jakarta: Badan Pengawas Perdagangan Berjangka Komoditi.

Bappebti. 2018. Data Alamat Gudang Srg Yang Dibangun Oleh Pemerintah Dan Sudah Mendapatkan Persetujuan BappebtiSebagai Gudang SRG. Jakarta: Kementerian Perdagangan.

BlitarKab. 2013. Resi Gudang, Tingkatkan KesejahteraanPetani. http://www.blitarkab. go.id/ 2013/04/24/resi-gudang-tingkatkan- kesejahteraanpetani/. Diakses 12/12/2018.

Briones, Roehlano. Tolin, Lovely Ann. 2016. Warehouse Receipts As A System For Improving The Efficiency Of Rice And Corn Marketing In The Philippines. Philipines: Econstor.

CBS News. 2017. The Future of Farming. https:// www.cbsnews.com/news/the- future-of-farming-maybe-below-the- soil/. Diakses 28 Desember 2018.

CNBC News. 2017. Underground Farming in

London. https://www.cnbc.com/2018/08/

30/in-london-theres-an-underground- farm-growingsalad-without-soil.html. Diakses 29 Desember 2018

Erwidodo, Erma Suryani, Iwan Setiajie Anugerah.

2014. Analisis Kinerja Dan Kendala Penyebarluasan Sistem Resi Gudang Di Indonesia. Jakarta: Pusat Sosial Ekonomi Dan Kebijakan Pertanian Badan Penelitian Dan Pengembangan Pertanian Kementerian Pertanian.

Fachruddin, Achmad dan Lestari Ayu. 2017.

Evaluasi Prasyarat Keberhasilan Sistem Resi Gudang di Kabupaten Bantul. Yogyakarta: Journal of Agribusiness and Rural Development Research, Fakultas Pertanian, Universitas Muhammadiyah Yogyakarta

Heizer Jay dan Barry Render. 2015. Manajemen Operasi: Manajemen Keberlangsungan dan Rantai Pasokan, edisi 11. Jakarta: Salemba Empat.
Khasanah, Ukhwatul. 2016. Efektivitas Implementasi Sistem Resi Gudang Komoditi Gabah (Studi pada Koperasi Niaga Mukti) di Kabupaten Cianjur. Yogyakarta: Thesis S2 Manajemen Agribisnis Universitas Gadjah Mada.

Liliyah, Arie. 2016. Sistem Resi Gudang, Berkaca dariKesuksesanBulgaria.

https://swa.co.id/ swa/trends/sistem-resi- gudangberkacadari- kesuksesan- bulgaria. Diakses 18 Desember 2018.

Onumah, G and Coulter, J. (2002). The Role Warehouse Receipt Systems in Enhanced Commodity Marketing and Rural Livelihoods in Africa. Food Policy 27 (2002) 319-337

Onumah, G. (2010). Implementing Warehouse Receipt System in Africa Potential and challenges. The African Journal of Agricultural and Resource Economics, 1(1) 1-18.

Permendag No 26. 2007. Barang Yang Dapat Disimpan Di Gudang dalam Penyelenggaraan Sistem Resi Gudang. Jakarta: Sekretariat Jenderal Departemen Perdagangan Biro Hukum.

Satriyo, Angrito Bimo. 2014. Pelaksanaan Pembinaan Sistem Resi Gudang Di Kabupaten Blitar (Studi Di Dinas Perindustrian dan Perdagangan, Dinas Pertanian dan Bank Pembangunan Daerah Jawa Timur di Kabupaten Blitar). Malang: Fakultas Hukum Universitas Brawijaya.

Undang-Undang Republik Indonesia Nomor 9

Tahun 2006. 2006. Sistem Resi Gudang. Jakarta: Kementeri Hukum Dan Hak Asasi Manusia Republik Indonesia.

Webster, Scott. 2009. Principles of Supply Chain Management $2^{\text {nd }}$ Edition. Charlestown: Dynamic Ideas.

Widyarto, Agus. 2012. Peran Supply Chain Management Dalam Sistem Produksi Dan Operasi Perusahaan. Surakarta: Fakultas Ekonomi Universitas Muhammadiyah Surakarta. 